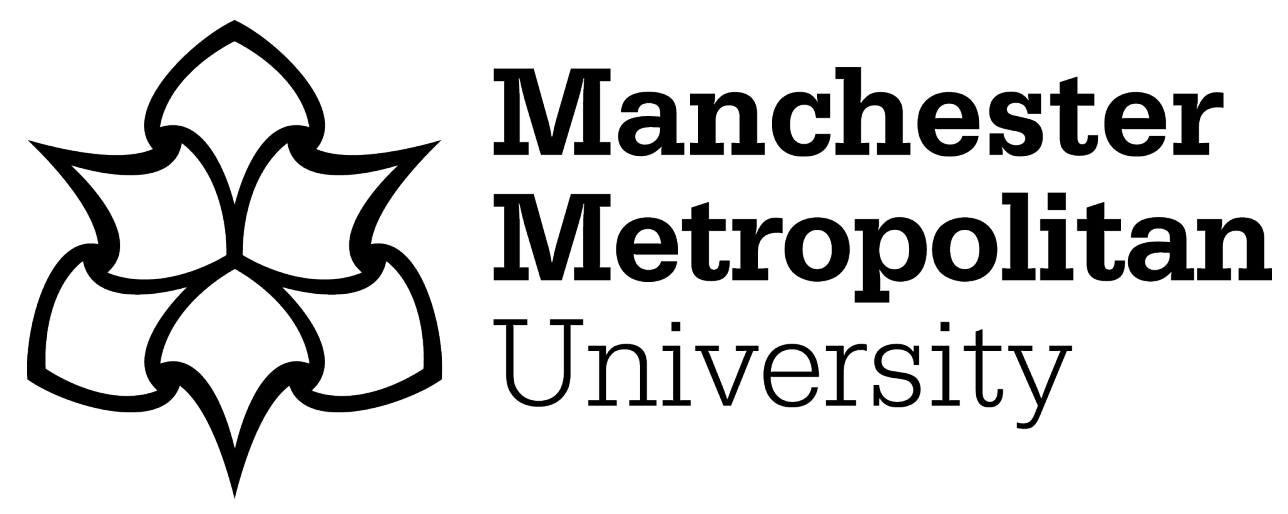

Warnaby, Gary ORCID logoORCID: https://orcid.org/0000-0002-6696-6671 (2019) The Victorian arcade as contemporary retail form? History of Retailing and Consumption, 5 (2). pp. 150-168. ISSN 2373-518X

Downloaded from: https://e-space.mmu.ac.uk/623016/

Version: Accepted Version

Publisher: Taylor \& Francis

DOI: https://doi.org/10.1080/2373518X.2019.1642565

Please cite the published version 
The Victorian arcade as contemporary retail form?

\section{Gary Warnaby}

Institute of Place Management, Manchester Metropolitan University

Corresponding author:

Professor Gary Warnaby,

Institute of Place Management,

Manchester Metropolitan University,

Faculty of Business and Law,

All Saints Campus, Oxford Road,

Manchester,

M15 6BH,

United Kingdom.

E: g.warnaby@mmu.ac.uk. 


\title{
The Victorian arcade as contemporary retail form?
}

\begin{abstract}
This paper analyses ground floor retail occupancy trends in Barton Arcade in Manchester, UK, from its construction in the 1870 s to the present. The paper begins by discussing the development of arcades and acknowledges their importance as a retail built form, before discussing their relative demise in the twentieth century. Analysis of occupancy data from Slater's/Kelly's Directories (1876-1965) and Goad plans (1967 onwards) reveal significant continuities in occupancy, as well as trends towards an experiential orientation of the retail activity within the arcade, which suggests that an arcade which was perceived in the mid-1980's to have little future might have successfully found a new lease of life. The paper concludes by discussing the implications for a continuing contemporary role for Victorian Arcades such as the Barton Arcade, and for taking a microhistorical perspective in the study of retail history.
\end{abstract}

Keywords Arcade, Barton Arcade, Retail Location, Retail Change, Microhistory. 


\section{Introduction}

It has been argued in the context of marketing that historical study "helps to establish an identity for a discipline by providing some idea of where it is and what it is ${ }^{\prime 1}$. With regard to retailing, Hollander likens historical study to a rearview mirror, and calls for more retail-oriented historical research to inform future industry development ${ }^{2}$. This is arguably of particular relevance to recent retail history, through its ability to enhance understanding of subjects that are inherently present- and futureoriented $^{3}$. However, Alexander notes the limited use of historical method within retail management studies, and posits various reasons as to why this might be $\mathrm{so}^{4}$. Whilst the situation has improved in recent years ${ }^{5}$, many aspects of retail study would benefit from a more overt historical perspective. This paper considers the potential contemporary role of the historic urban form of the Victorian shopping arcade, and identifies issues relating to the utility of taking such a perspective in this specific context.

Alexander notes that much research into retail history takes a prosopographical approach ${ }^{6}$, focused on individual companies or institutions (e.g. the co-operative movement). This paper adopts such an approach, focusing on a particular retail form - the arcade - and further narrows that focus to detailed examination of one particular case - Barton Arcade, the surviving example of five arcades built from 1870-1900 in the northern English city of Manchester. Through longitudinal analysis of its retail ground floor occupancy since its opening in 1871, highlighting patterns of both change and continuity evident therein, we can throw light onto phenomena that might illuminate understanding of the role of the historic retail form of the arcade in the contemporary retail landscape, and how this role may potentially develop into the future.

\section{The Development of the Arcade as a Retail Form}

Geist defines an arcade as "a glass covered passageway which connects two busy streets and is lined on both sides with shops"7. First developed in Paris in the late eighteenth century, arcades are usually traced back to the Galeries de Bois, which comprised rows of shops separated by covered passageways illuminated by skylights, and constituted as part of the Palais Royal in Paris ${ }^{8}$. As a separate building type, arcades developed in the early nineteenth century, as the success of the Galeries de Bois was copied elsewhere in Paris and in French provincial towns, and internationally ${ }^{9}$, with the first British example being the Royal Opera Arcade in London dating from $1817^{10}$. 
By the mid-nineteenth century, Mackeith states that the term 'arcade' was deemed appropriate for a variety of covered shopping developments ${ }^{11}$, and arcades were a key element of the European retail and urban environment during the second half of the nineteenth century ${ }^{12}$. Furthermore, arcades were symbols of modernity and vitality through their innovative use of architectural design, building materials and techniques ${ }^{13}$, and during this time, contributed to a wider process of civic boosterism of the Victorian city ${ }^{14}$.

However, by the start of the twentieth century, the arcade's heyday was already passing ${ }^{15}$; arcades constructed in the early twentieth century were generally smaller and less architecturally ambitious than their nineteenth century predecessors ${ }^{16}$. Geist argues that the arcade became "dependent on other structures and barely recognizable in its reduced form", which included inter alia as a courtyard in office and other public buildings, a pedestrian level above or below vehicular traffic, and as a pedestrianised street ${ }^{17}$. From this time onwards, arcades were often marginalised in new shopping development schemes, especially after the Second World War ${ }^{18}$, since when, changes in consumption patterns (and the consequent development of the retail built form) seemed for a time at least, to render them increasingly redundant. According to Mackeith, the arcade "had become by 1970 an historic building type doomed to extinction" ${ }^{\prime 19}$.

However, the historical significance of the arcade as a retail form is widely acknowledged. For example, many of the architectural features of - and merchandising practices adopted by - the shops within arcades have been regarded as being precursors of the department stores that were such a significant feature of urban retailing in the later nineteenth century ${ }^{20}$. Similarly, Howard and Stobart suggest many of the characteristics of the arcade are antecedents of - and present within - the twentieth century shopping mall, with a consequent blurring of the distinctions between these building forms ${ }^{21}$.

Moreover, some arcades dating from the nineteenth century have endured, and have been more positively re-evaluated, as their individual architectural character could potentially contribute to the differentiation of increasingly homogenised urban shopping destinations. In his "necessarily fragmentary" gazetteer in 1985, Geist lists almost 300 architecturally significant arcades in various countries ${ }^{22}$. Of these, 127 are described as 'standing', 20 as 'modified' or 'remodeled', and 12 as 'restored' or 'renovated'. Contemporaneously, MacKeith identifies 118 "extant arcades" in Britain ${ }^{23}$. In the intervening period, some have inevitably disappeared because of urban redevelopment, but others have seen active attempts at preservation, with attempts to grant UNESCO World Heritage status in some cases ${ }^{24}$. 
With such preservation efforts, there is an inevitable tension between commercial development and authenticity ${ }^{25}$. Some arcades - such as the Galleria Vittorio Emanuele II in Milan, and the Burlington Arcade in London - have become symbols of those cities, and tourist attractions in their own right. Here, heritage is explicitly emphasised: the Burlington Arcade website (www.burlingtonarcade.com) has as a strapline 'Curators of London style since 1819'. Moreover, linked to - and resonating with - the original upmarket clientele of such $\operatorname{arcades}^{26}$ and their antecedents such as shopping galleries ${ }^{27}$, the retail activity therein focuses on luxury products. Indeed, luxury-oriented retailers will value the experiential benefits of such historic locations, with their connotations of 'authenticity'28. However, Plevoets and Van Cleempoel note that the meaning of this term will be understood differently within the different contexts of heritage conservation and retail design. They go on to identify various, somewhat generic, "aspects of authenticity" (based on UNESCO guidelines) and, in the specific context of arcades, identify a number of subcategories relating to their form and design, the materials used in their construction, and also their "spirit and feeling" (incorporating factors such as the scale and prestige of arcade tenants). ${ }^{29}$

Moreover, in addition to the role of iconic arcades in major tourist centres, there is now a greater awareness of the potential of this historic retail built form more generally, to create a sense of perceived differentiation of a town or city's retail provision. This arises from the perception of the historical authenticity of the arcade as a built form, as well as the distinctive independent and/or luxury retailers seemingly more likely to be located therein. We now move to consider this more fully in the context of Barton Arcade in Manchester.

\section{Arcades in Northern English Cities in the Late Nineteenth Century}

The late nineteenth century witnessed a burgeoning of arcade building in the towns and cities of northern England ${ }^{30}$. MacKeith's gazetteer of British arcades lists 61 as built between 1870-1900, with 27 built in Yorkshire and Lancashire alone, in towns, such as Accrington, Barnsley, Colne, Halifax, Harrogate, Huddersfield, Hull, Ilkley, Keighley, Oldham and Southport ${ }^{31}$.

However, foremost among northern cities in the development of arcades was Leeds. The first arcade built there, in 1877-8, was Thornton's Arcade, the success of which, according to Grady "encouraged emulators"32. These included the Grand Arcade (1896-8, now Grade II listed, and recently redeveloped as a retail space for local start-up businesses, currently branding itself as the 'Home of Leeds Independents'), the Queen's Arcade (1988-9, another arcade currently focused on independent retailers), the Victoria Arcade (1898, now demolished), and built between 1898-1900, the County 
Arcade and its adjunct, the Cross Arcade (again, Grade II listed, and now a central element of the upmarket Victoria Leeds retail development). According to Grady, these arcades and the new City Markets "formed the central features of what amounted to a complete transformation of the shopping centre between 1975 and 1909"33, and indeed, the surviving arcades are now regarded as an important aspect differentiating the city as a retail destination.

In another comparable northern city, Newcastle upon Tyne, arcade-building activity came slightly later, with the small Central Arcade in 1906 (located in the Central Exchange building, dating from 1840, and now the only remaining arcade in the city), and the Handyside Arcade from 1906 (demolished in the late 1980 s as part of comprehensive city centre redevelopment). There was also the earlier Royal Arcade (dating from 1832 and demolished in the early 1960s).

Manchester was no exception to this arcade-building trend, with five constructed in the thirty years after 1870. Barton Arcade was the first, built in 1871, and occupying an area between Deansgate (a long established shopping street) and a small side street leading to St Ann's Square, approximately 120 metres northwards of the Kendal Milne department store on the opposite side of Deansgate. The other arcades built at this time were Deansgate Arcade, Exchange Arcade (both of which also had entrances onto Deansgate), Victoria Arcade (which was part of a block between Deansgate, St. Mary's Gate and Victoria Street), and Lancaster Avenue (which connected the Corn Exchange to Victoria Station). All five arcades were located in close proximity, but Geist notes the fact that none connected commercial streets of equal activity was a reason why they did not flourish in commercial terms. Indeed, Geist describes Lancaster Avenue as "insignificant" in architectural terms, and with regard to Victoria Arcade, cites a description in the Manchester Evening News from 1927 as being "intended to rank with its neighbour, the Barton Arcade, an idea that has never fructified"34.

Barton Arcade is the only arcade that survives to the present day. Of the other Manchester arcades, the Victoria and Exchange Arcades were destroyed in bombing raids in the Second World War, and Deansgate Arcade and Lancaster Avenue were demolished in the mid-1950s and mid-1970s respectively. Hence, Barton Arcade is the focus here, which - in line with Hollander's contention that looking in the rearview mirror might inform future industry development - considers the extent to which taking a historical perspective in relation to its occupancy over time might inform consideration of a contemporary role for the Victorian arcade. Geist describes Barton Arcade as "still standing in its original state ${ }^{\prime 35}$, and the structure (restored in 1982), is Grade II listed, with the List Entry noting that Barton Arcade is a "fine example of Victorian shop-and-office arcading" ${ }^{36}$. Thus, consistent with other historic arcades in a similar state of preservation mentioned above, it seems that there could be a contemporary role for the Barton Arcade. 


\section{The Barton Arcade}

Barton Arcade is located on Deansgate, the major street running north to south in Manchester city centre, which was a long established mixed use residential, manufacturing and commercial area: by 1845, Slater's Directory listed 209 businesses on Deansgate ${ }^{37}$. However, Deansgate's deficiencies as an effective thoroughfare were increasingly acknowledged, and as part of a wider process of urban improvement (especially in terms of traffic flow in the city), there were initiatives to widen main streets $^{38}$. In Deansgate, this process culminated in the Manchester Corporation Waterworks and Improvement Act 1869, which sanctioned compulsory purchase of premises on the road in order to facilitate its widening (from six to 18 metres), which began in 1870. Bertramsen argues that these developments accelerated the existing process of gentrification, stating that "after 1870 parts of the street were gradually to acquire a more genteel clientele. It was literally opened up to the emerging professional and commercial classes" ${ }^{\prime 39}$, and Deansgate became one of the major shopping streets of Victorian Manchester, with contemporary comparisons being made with London's Regent Street ${ }^{40}$, and challenging the predominance of Market Street in the city's retail provision. Part of this process was the construction of new retail and commercial premises, and the first to be built on the widened Deansgate were Ward's Buildings and Barton Arcade. Bertramsen states that at street level, both were ostensibly retail buildings housing a number of shops, but they also served to facilitate the expansion of high-density commercial and professional employment in the area, as by 1879 the upper floors of these two buildings housed 146 offices, occupied by 123 different establishments ${ }^{41}$.

According to Geist, Barton Arcade's 55-metre long façade was influenced by the Galleria Vittorio Emanuele II in Milan. The two lower storeys (which are treated as one) fronting Deansgate are glass, comprising nine bays (each divided horizontally by shop fascia boards, and vertically by ornamental piers), and united by ironwork arches (see Figure 1). In Pevsner's The Buildings of England series, this façade is described as "long and thoroughly ignorant", yet behind the façade, the interior is described as "probably the best example of this type of cast-iron and glass-roofed arcade anywhere in the country" ${ }^{\prime 2}$.

\section{INSERT FIGURE 1 HERE}

The arcade has four storeys, and its site is wider than it is deep. The original interior street level plan had 13 shops "of varying dimensions with elegantly bowed entrances and two staircases to 
the upper stories", occupied by small offices and showrooms (still with their original plate glass and timber fronts), and accessible from continuous cast-iron galleries which connect with the ends of the arcade wings in a semicircle ${ }^{43}$ (see Figure 2). Geist notes that the aesthetic effect of the arcade space is determined by the iron railings of the galleries and by the complex vaulted glass roof, which reaches 53 feet and has two octagonal cupolas at the points of intersection of the arcade wings. A schematic diagram of the ground floor plan, based on an illustration in Geist's book (with the outlets numbered according to this illustration), is shown in Figure $3^{44}$.

INSERT FIGURE 2 HERE

INSERT FIGURE 3 HERE

\section{Studying Retail Occupancy}

To look in the 'rearview mirror', analysing the retail occupancy of ground floor units in Barton Arcade from its opening in the 1870s to the present day in order to identify the types of retailers located therein (and any patterns of continuity and change), will inform understanding of the dynamics within one particular arcade. This detailed investigation, could potentially help identify a possible contemporary role for the Victorian arcade more generally through adopting a historical perspective, and in so doing contribute to understanding of how this retail form has developed since its heyday in the late nineteenth century.

Two main sources were used to access these occupancy data. The first relates to the period prior to 1967, using Slater's/Kelly's Retail Directories of Manchester, from which data were drawn at 4-6 year intervals from 1876 to 1965 . Kelly's was the largest publisher of directories to operate during the second half of the nineteenth century and in the early/mid twentieth century ${ }^{45}$, which allowed for data continuity over the period. These directories listed the occupants of individual premises (in the specific case of Barton Arcade, not just the retail-oriented occupants of the ground floor, but also occupants of the offices/showrooms of the upper storeys). However, from these data it is impossible to ascertain exactly which of the 13 units in the ground floor schematic (Figure 3) were occupied by specific retailers.

The second, more detailed, data source were Goad plans for Manchester, which enable the tracing of retail occupancy in Barton Arcade since the mid-1960s (relating to ground floor occupancy 
only). Goad plan data enable an understanding of occupancy at the level of the individual shop unit within the arcade, as they give a greater level of detail than the older directories, providing a bird's eye view, showing retail fascia name, product/service category, floor space 'footprint' and exact location of all retail outlets/vacant premises. As an example, Figure 4 provides an indication of the available data for Barton Arcade in the Goad plan for 1993. Goad plans of the shopping centres of towns and cities in England, Wales and Scotland (with populations in excess of 50,000) have been produced since 1967, and regularly updated thereafter.

\section{INSERT FIGURE 4 HERE}

The use of Goad plans as a source of spatial data is discussed by Rowley and Shepherd, who note that they "provide an excellent opportunity for cross-time comparisons" of retail activity within town and city centres ${ }^{46}$. Goad plans were analysed at approximately 2-3 year intervals from 19672018. Data are reported from the following years: $1967 ; 1969 ; 1971 ; 1973 ; 1975 ; 1977 ; 1980 ; 1983$; $1986 ; 1988 ; 1990 ; 1993 ; 1996 ; 1998 ; 2000 ; 2003 ; 2006 ; 2008 ; 2010 ; 2013,2015 ; 2018$. The choice of years was guided by the fact that initially Goad plans were produced biennially until the 1980s, and thereafter in relation to Manchester specifically, there are occasional gaps in map availability.

\section{Ground Floor Retail Occupancy of Barton Arcade using Retail Directories}

Analysis of data from the Slater's/Kelly's Directories between 1876 and 1965 (see Table 1) indicates that street level occupancy of Barton Arcade was characterised by significant stability. Thus, certain retailers occupied the same premises for many decades. H. G. Stephenson, a china and glass specialist, was the biggest retailer in the arcade (occupying three units), and is first mentioned in the 1881 directory, only disappearing from the ground floor in the 1961 directory (but later, in 1965, was showing as occupying first floor premises). From 1876-1933, there was a branch of Mudie's Library in Barton Arcade (which was also represented in various locations in London, and in Birmingham). Two footwear retailers (originally described in the directories as 'bootmakers'), were long-established retailers in the arcade; in particular, J. Edwards, which occupied the same premises throughout the period under study, until it finally closed in 2015. It was reputedly the oldest independent shoe shop outside London, located on the same site since it began trading in 1830 (predating Barton Arcade by some 40 years). Whilst the vast majority of the retailers in Barton Arcade were independent shops (although as mentioned above, Mudie's Library was a national firm), the Northampton-based 
manufacturer and multiple shoe retailer Manfield \& Sons ${ }^{47}$, also had a store in the arcade. Manfield \& Sons was another long-established retailer in Barton Arcade, first appearing in the 1896 directory (taking over premises from a previous bootmaker, Henry Timpson), and the company's last appearance in the records was in the 1980 Goad plan. Notwithstanding its description as a multiple retailer, over this period, Manfield \& Sons was a vertically integrated company incorporating both manufacture and retailing, occupying a quality oriented mid-market position, and until 1950 was privately-owned.

\section{INSERT TABLE 1 HERE}

There were other, shorter-lived retailers located in Barton Arcade (i.e. only mentioned once in the selected retail directories), featuring an eclectic range of products, including a chemist, confectioner, hatter (all 1876), jet ornament manufacturer (1886, perhaps capitalising on jet's fashionability in the Victorian period), and costumiers (1939). However, certain merchandise categories, such as footwear and china and glassware, seemed to be staples of the Barton Arcade, along with food and beverage provision. Directories indicate the presence of a café in the same premises from 1876 until the mid-1950s, albeit sequentially under different ownership: e.g. the Exchange Dining Rooms in 1876, Louis Krause (described in the directories as 'Restauranteur') mentioned from 1886-1904, followed by the Barton Arcade Café (from the 1911 directory to the 1929 directory), and then the Squirrel Café, mentioned in the 1933 directory until the 1954 directory. Indeed, the period covered by the Slaters/Kelly's directories could be regarded as one of significant continuity as far as retail occupancy was concerned. This is particularly evident in the inter-war years, where there was minimal change in the retailers located within the arcade.

\section{Ground Floor Retail Occupancy of Barton Arcade using Goad Plans}

Data relating to retail occupancy within Barton Arcade from the mid-1960s, provided by Goad plans of Manchester (from their initial publication in 1967), is indicated in Table 2. As mentioned above, these data are more comprehensive than in the retail directories, enabling investigation of occupancy of the individual shop units numbered 1-13 based on the ground floor plan reproduced in Geist and depicted in Figure 3. 


\section{INSERT TABLE 2 HERE}

The continuity and stability mentioned above is echoed initially in the Goad plans from 1967 onwards. Prior to the mid-1970s, all ground floor units were occupied. Notable here is Ellwoods drapery store, which occupied five of the original 13 units through this period, being first mentioned in the 1939 Directory, where it is described as a 'silk merchant', and subsequently expanding its spatial footprint into the Arcade from its original store with a frontage onto Deansgate. There were also commercial users, including an employment bureau and the Coal Utilisation Council (later the Solid Fuel Advisory Council, which made its appearance in the 1957 Directory described as an information centre', taking over the premises previously occupied by the cafes mentioned above).

However, by the mid-1980s, MacKeith states that most of its shops were empty, and (notwithstanding the fact that it is only approximately 320 metres away from modern shopping centre developments in the city centre) describes Barton Arcade as " $[t]$ oo far away from new shopping in and around Arndale centre. Shops will remain empty" ${ }^{\prime 8}$. Ellwoods had disappeared, and the five units comprising the store split (three of which were vacant). Indeed, in 1983, only five units in Barton Arcade were occupied. This is possibly linked to restoration work in 1982, which MacKeith describes in terms of the arcade being "redecorated, roof repaired, shop fronts replaced with copies of original, all glass doors installed with arcade motif handle, new shop units and exit/entrance created on St. Ann's elevation opposite St. Ann's Arcade. New floor and plants added"49. This work can be seen as part of a trend for arcade restoration in this period, perhaps as a consequence of the conservation movement, and according to MacKeith, "either a reappraisal of the value of the arcade as small unit retailing or because it is a cheap alternative to redevelopment". Thus, five such 'facelift' schemes occurred in the late 1960s, 16 in the 1970s and 17 between 1980, and MacKeith's comments in 1986 although there also exists a parallel narrative of demolition (as reported above in the context of arcades in the towns and cities of northern England).

MacKeith notes "[o]verall the [restoration] projects are successful, and in most cases there has been great financial improvements as tenants have taken shops which had lain empty for years" ${ }^{\prime 21}$. This appears to be the case with Barton Arcade, with the 1986 Goad Plan showing all but one unit as occupied, indicating that restoration work had increased the arcade's attractiveness to potential tenants. Thus in 1986, Barton Arcade housed a mixture of national brands (e.g. Osborne \& Little soft furnishings, Oddbins wine merchants), a wine bar, and independent specialist retailers (with an orientation towards fashion). 
The remainder of the 1980 s were a period of relative stability with most units under single continuous occupation. However, by the time of the 1990 Goad plan, Unit 12 (previously occupied by Ganders Wine Bar) had been subdivided into smaller units, mainly occupied by fashion retailers, although there was a residual food and beverage presence, with a sandwich shop in Unit 12a. Indeed, over the next decade, the retailer mix in Barton Arcade seems to indicate a focus on fashion of a more design-led and 'edgy' nature. Such offerings were provided by independent retailers, and perhaps indicative of the relatively small size of the units themselves (which were arguably too small for the increasingly prevalent specialist multiple retailers who were becoming more dominant in the UK retail landscape). The small number of multiple retailers/national brands (e.g. Osborne \& Little, Oilily, etc.) that were located in Barton Arcade generally had a niche/specialist offer that did not neatly fit in the more mainstream offering of large managed shopping developments such as the Arndale Centre (dating from the mid-1970s). Moreover, brands such as Osborne \& Little and Oilily occupied more upmarket positions in their respective markets, and with limited stand-alone store networks, were arguably not perceived in the same way as more mass-market multiple retailers. Consequently, their location within the Barton Arcade could be seen as consistent with the notion of the arcades as a more individualistic and 'authentic' retail experience arising from its particular physical characteristics and more exclusive retail mix.

Retail occupancy since the early 2000s reveals a somewhat complex pattern of stability and flux. On the one hand, some units were occupied by the same retailer for a prolonged period (notably, J. Edwards, mentioned above, but with other examples of long-term occupancy over decades). In contrast, occupancy trends in other units are characterised by regular tenant 'churn'. Indeed, some retailers have led a somewhat peripatetic existence, even within the confines of the arcade; for example, the fashion retailer Oilily occupied one unit from 1990 onwards, until the 2006 Goad plan reveals an additional unit occupied by this retailer (with merchandise ranges in the two units now separated between ladieswear and childrenswear). However, the 2008 Goad plan indicates both merchandise ranges combined in a single unit again; but notably, this was a different unit to before. By the time of the 2010 Goad plan, the company had disappeared entirely from the arcade. A further trend (echoing one also evident in the earlier directories) apparent in relation to retailer 'churn' is that some units are occupied by successive retailers selling the same type of merchandise. For example, Unit 3 has been occupied by two different companies selling lighting, and Unit 5 has been occupied by two off-licences over the years. Unit 12a has been occupied by a sandwich shop since 1993, and indeed, this unit has been reincorporated with Units 11, 12 (i.e. Ganders Wine Bar in the 1980s), and $12 \mathrm{~b}$ to create the current larger independently owned food and beverage occupier PotKettleBlack. 


\section{Upper Floor Occupancy}

The retailing of services - primarily food and beverage provision - at ground floor level has been present in Barton Arcade from its earliest days, and continues to the present day, with another restaurant (a more upmarket Spanish-themed restaurant/bar and delicatessen), a travel agent (Austravel) from the early 1990s to the early 2010s, and subsequently STA Travel (occupying a different unit), and various hairdressing outlets over time. These current food and beverage outlets also provide seating in the arcade itself, which serves to animate the space of the arcade (see Figure $5)$.

INSERT FIGURE 5 HERE

However, it is in the offices and showrooms of the upper floors where this service provision is most evident. Consistent with Bertramsen's view that these offices were originally "the workplaces of an emerging white collar middle class" ${ }^{25}$, successive pre-1965 directories list an eclectic range of service providers located therein, including architects, solicitors, brokers (cotton, yarn, and stocks and shares etc.), a music teacher, and various medical professionals (including surgeons, dentists, an electrotherapist and a masseur). Whilst it is not the main purpose of this article to discuss occupancy on the upper floors, some discussion of this aspect from a historical perspective does highlight some potential continuities, and points a way forward for a possible future role for the arcade. The recently refurbished offices on the upper storeys in Barton Arcade are now occupied by a more contemporary - and more homogenous - mix of service providers in the form of PR/media businesses, and shared workspaces/hot-desking facilities etc. The arcade's current owners capitalise upon the historic architecture (described as "charming" in the arcade's website, which like the websites for other arcades noted above, emphasises its longevity, with the strapline 'Mcr since 1871' - see http://bartonarcade.co.uk).

Furthermore, and resonating with the social uses and prestige associated with the shopping galleries which were the antecedents of $\operatorname{arcades}^{53}$ - and the original nineteenth century customer profile of many established arcades ${ }^{54}$, arising from their exclusivity - the space of the Arcade is now being expanded upwards, to incorporate a rooftop members bar. Such developments are also occurring at a subterranean level, in the form of a basement members' lounge (incorporating event space and private cinema). This basement lounge uses the Arcade's extensive cellar space two levels below ground, which spreads out underneath Deansgate, and from 1868-1961 was used by H. G. 
Stephenson (a long-standing retail tenant mentioned above), and largely untouched since ${ }^{55}$. It seems that many principles of adaptive re-use of historic buildings for retailing ${ }^{56}$ - especially in relation to service and experiential retailing - are relevant here. Thus, an appropriate blend of architectural authenticity and contemporary use may yet provide a new, profitable lease of life for a location that had been essentially written-off by MacKeith over 30 years ago.

\section{Concluding Comments}

This longitudinal analysis of retail occupancy of a historic arcade is situated within a tradition of microscale retail location, defined by Brown as "pertaining to the siting of outlets within planned shopping centres and unplanned shopping districts" ${ }^{\prime 57}$. Indeed, the example of the peripatetic Oilily store(s) in Barton Arcade is perhaps testament to Brown's reporting of the view that "a few metres can make all the difference between success and failure in retailing"58. Furthermore, the prosopographical approach taken here - a detailed longitudinal study of retail occupancy within one particular Victorian arcade - is consistent with the principles of microhistory, characterised by reducing the scale of observation to the microscopic scale, through an intensive analysis of documentary material, that will hopefully reveal factors previously unobserved ${ }^{59}$. In this particular case, the significant continuities of retail occupancy is a subject for further investigation. Thus, whilst this study focuses on retail occupation within the micro-level of the Barton Arcade, it will be valuable for future research to consider the wider Deansgate/St Ann's Square/King Street area within which it is located, in the broader spatial context of changing patterns of retail provision within Manchester city centre. Detailed analysis of retail occupancy across such a wider areal coverage since the mid-1960s is possible using Goad plans, which could help determine wider spatial patterns of retail change and continuity in the city centre (for example, in terms of determining if and where any retailers in Barton Arcade were located before and after their occupancy of premises in the arcade). Such activity would surely reveal new insights, consistent with Levi's contention that, when taking a microhistoric perspective: "Phenomena previously considered to be sufficiently described and understood assume completely new meanings by altering the scale of observation"60.

Proponents of microhistory suggest that this approach - focusing on specific cases in minute detail - can also exemplify general concepts ${ }^{61}$. Indeed, Ginzberg emphasises the importance of context in microhistorical studies ${ }^{62}$. The case of the Barton Arcade appears to resonate with the experience of other surviving arcades mentioned above (in cities such as London and Leeds) suggesting that the nature of the Victorian arcade has facilitated the continued occupancy of small-scale retail premises. Such premises are either independently-owned or occupied by upmarket/luxury brands, for whom 
the character of the arcade space and its adaptive reuse can serve as an effective means of market positioning and differentiation, both for the brands themselves, and also for the towns and cities within which they are located. Indeed, the connotations of 'heritage' arising from the longevity as a building form of surviving arcades is a common trope in promoting their appeal. Such developments suggest that there is still a contemporary role for this historic retail built form as its retail provision adapts to contemporary trends. However, further empirical work is needed to investigate longitudinal patterns of occupancy in other Victorian arcades in a variety of towns and cities to ascertain whether the character of the retailers (and their marked continuity, in some cases) in Barton Arcade is indicative of a more general pattern.

Inevitably, Levi argues that building a narrative using a microhistorical approach has limitations, one of which "is that of incorporating into the main body of the narrative the procedures of the research itself, the documentary limitations, techniques of persuasion and interpretive considerations"63. Thus, there were limitations in using the Goad plans for this purpose (including, for example, illegible entries on some of the older handwritten plans). Moreover, without interrogation of those responsible for decisions made at the time, no rationales are available to explain some of the changes in occupancy over time (such as, for example, the peripatetic Oilily store), and the passage of time makes obtaining such rationales increasingly unlikely. Thus, according to Levi, "the researcher's point of view becomes an intrinsic part of the account ${ }^{\prime 64}$. However, notwithstanding this, trying to link what is happening at the micro scale in Barton Arcade, with retail trends in the broader city centre (and indeed, beyond) may enable a fuller understanding of the pattern of retail locational activity at both micro- and a wider, macro-scale to be achieved. 
Figure 1: Barton Arcade façade, from Deansgate

(Image: Author's own)

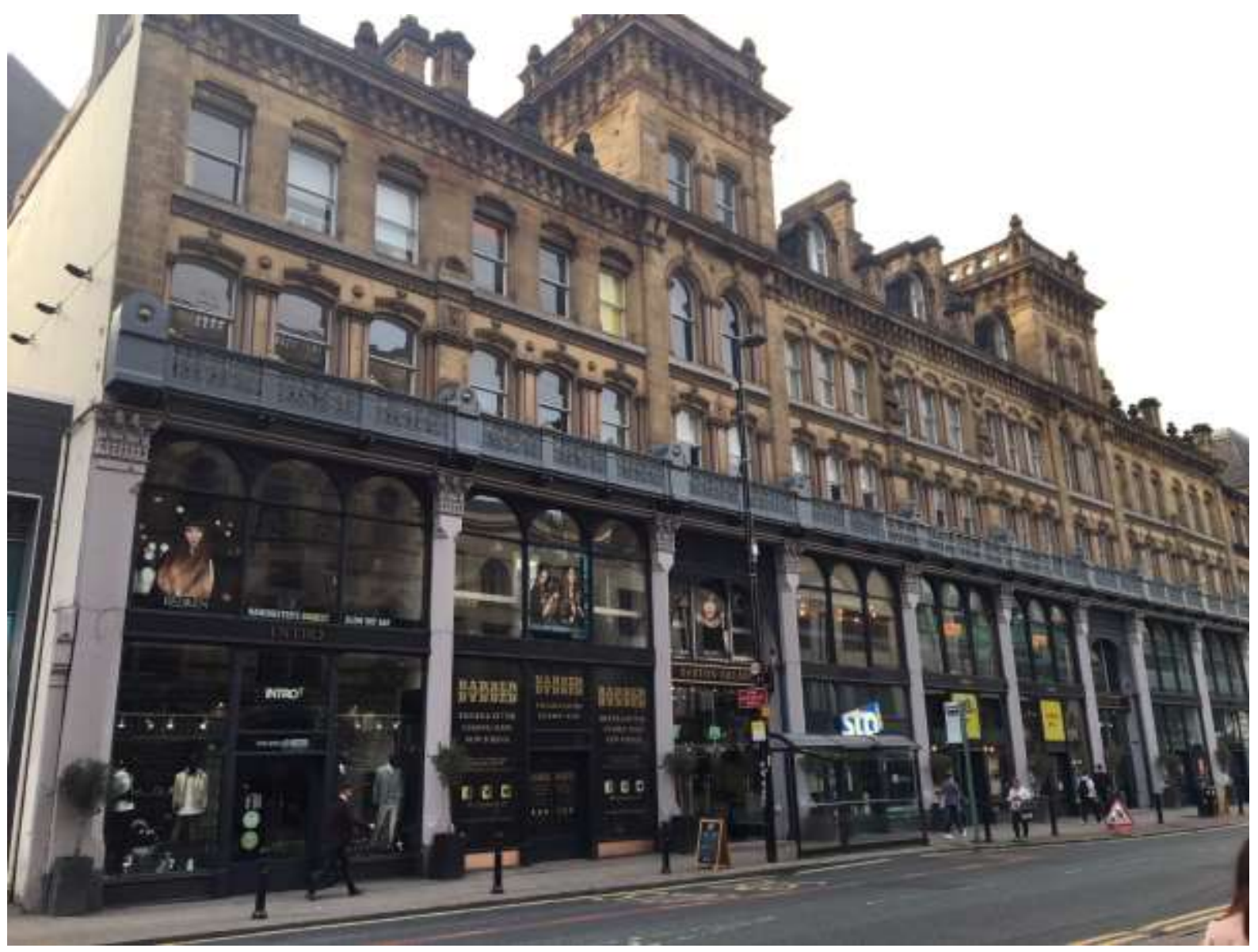


Figure 2: Barton Arcade interior

(Image: Author's own)

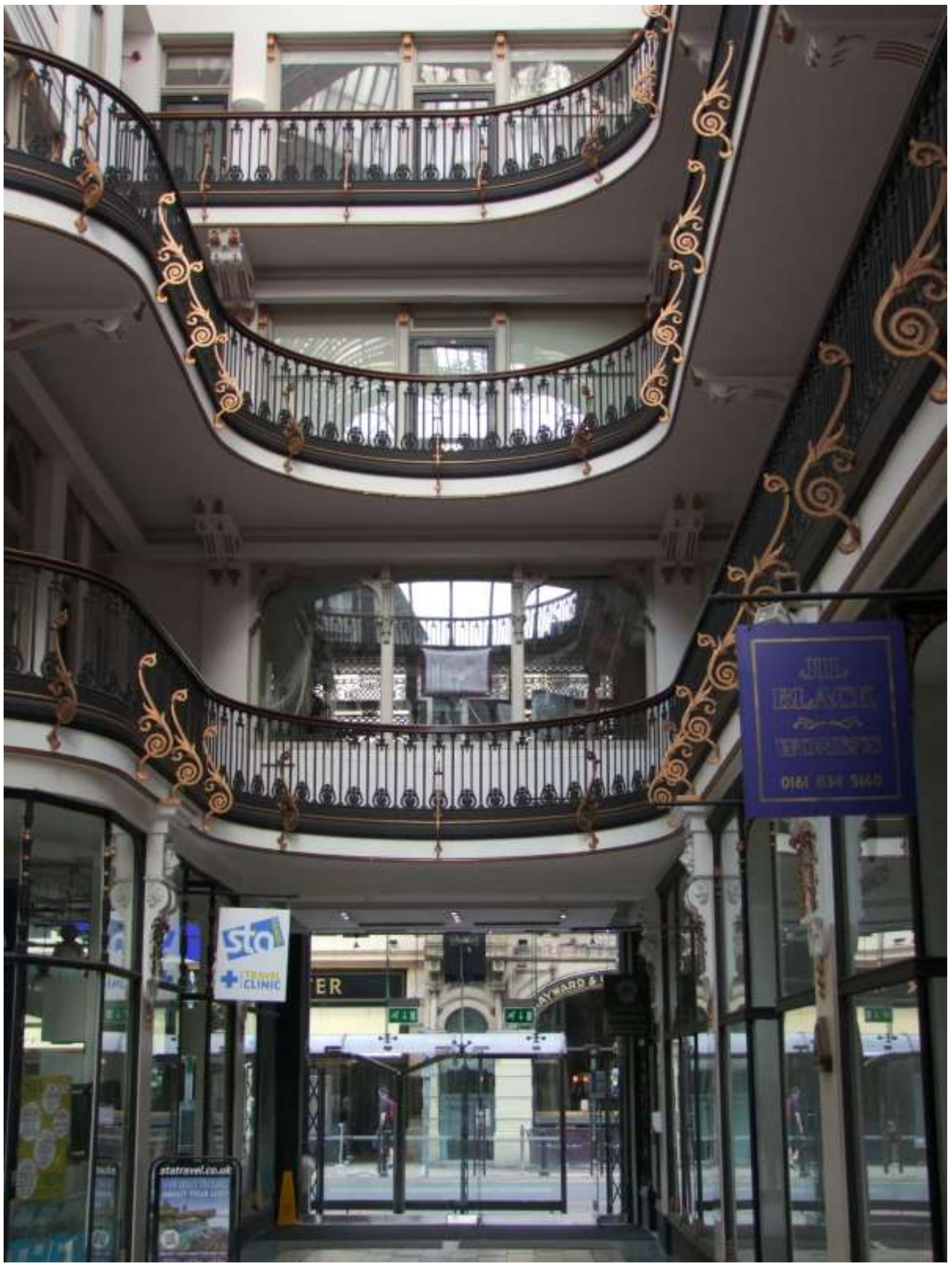


Figure 3: Ground Floor Schematic showing retail outlets (numbered)

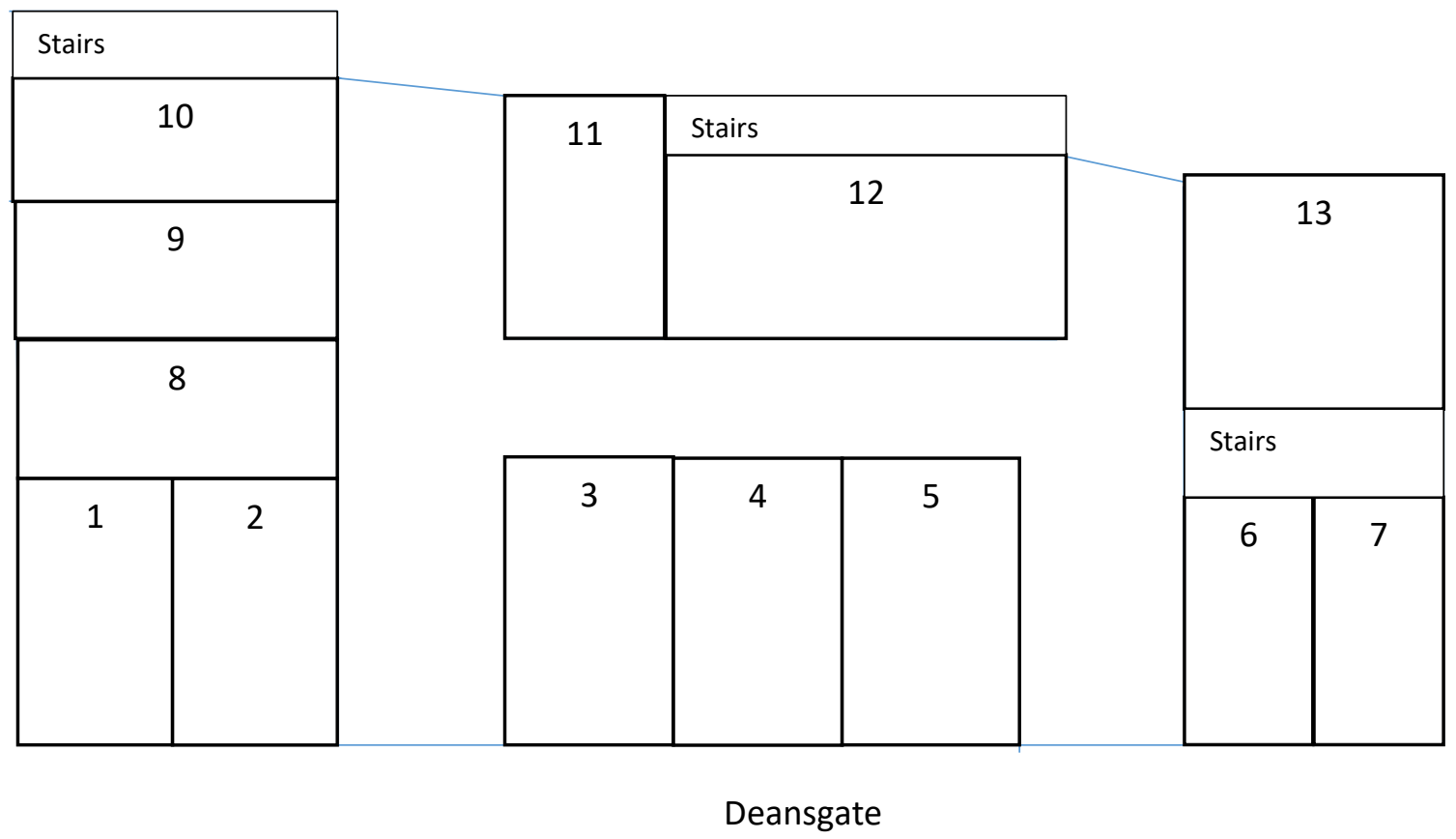


Figure 4: Barton Arcade in the 1993 Goad Plan

(Image: Author's own. Courtesy of Experian Limited. All rights reserved - includes mapping data licensed from Ordnance Survey. Crown Copyright 2018. Licence Number PU100019885)

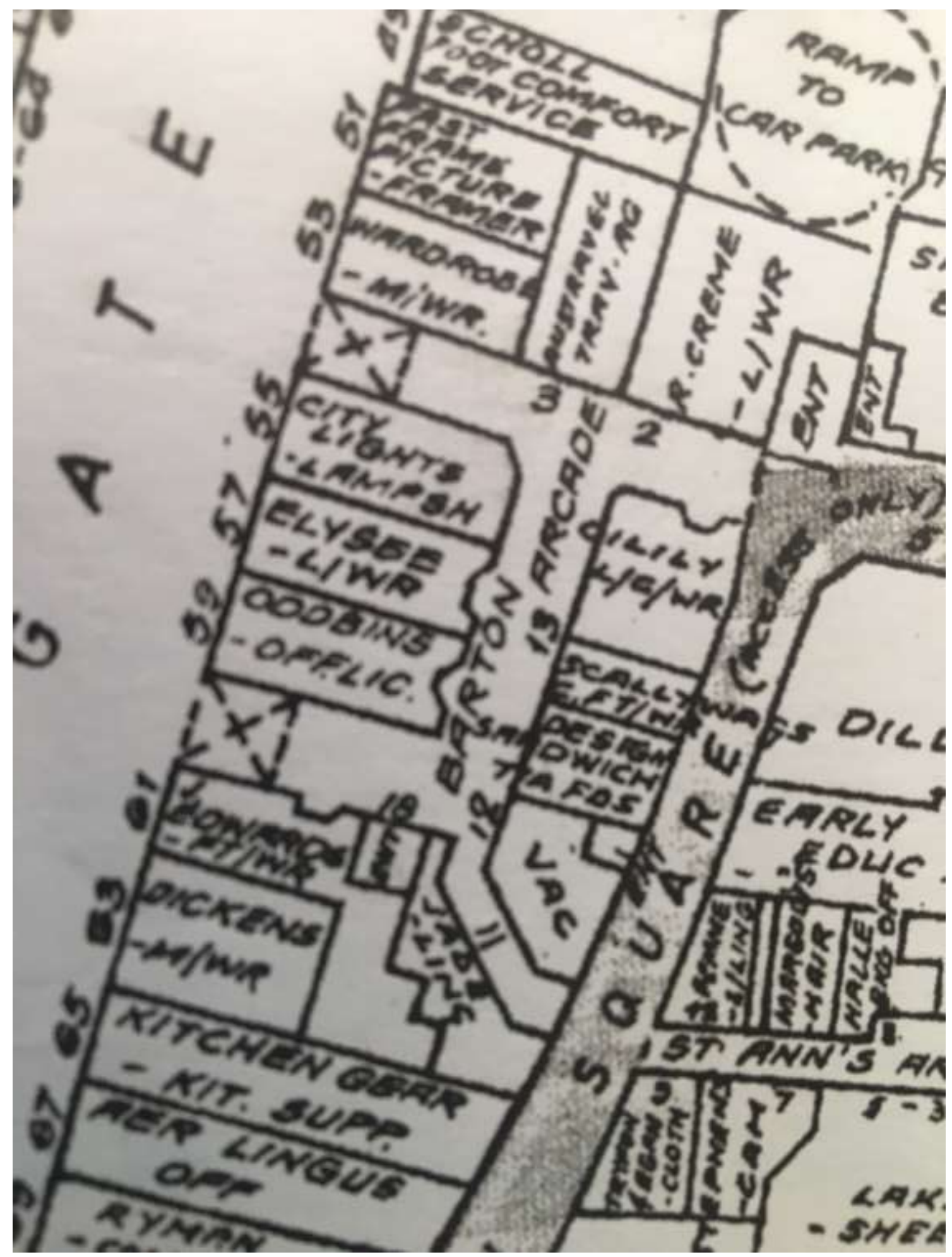


Figure 5: Food and beverage provision in the arcade space

(Image: Author's own)

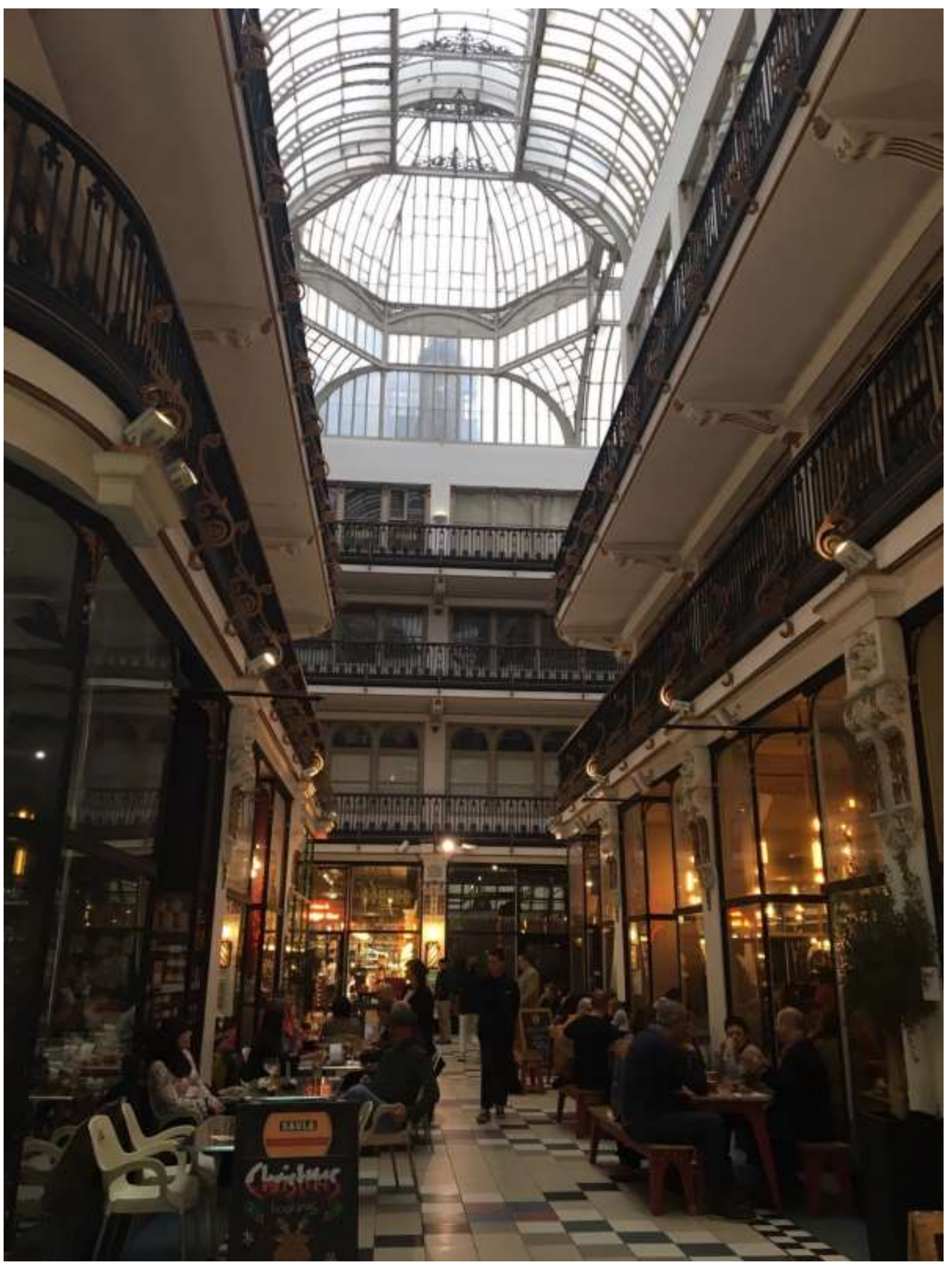


Table 1: Occupancy 1876-1965 from Retail Directories

\begin{tabular}{|l|l|l|}
\hline Retailer & Description of Business & Dates $^{\#}$ \\
\hline Edwin Johnson & Chemist & 1876 \\
\hline Mary E Hindley & Wool repository & 1876 \\
\hline Mrs Bakewell & Confectioner & 1876 \\
\hline Exchange Dining Rooms & Restaurant & 1876 \\
\hline Edwards \& Son & Bootmaker & $1876-1965$ (2015) \\
\hline E Henry \& Co & Music warehouse & $1876-1890$ \\
\hline Simpson \& Co & Hatters & 1876 \\
\hline $\begin{array}{l}\text { Mudies Library (later Mudies } \\
\text { Manchester Library) }\end{array}$ & Books & $1876-1933$ \\
\hline H G Stephenson & & \\
\hline Louis Krause & China \& glass dealer & $1876-1961$ \\
\hline Mary Brooks & Restaurant & $1882-1905$ \\
\hline Ward \& Co & Unknown & 1882 \\
\hline Scott J Hayward & Fancy repository & $1882-1911$ \\
\hline Henry Timpson & Jet ornament manufacturer & 1886 \\
\hline Manfield \& Son & Bootmaker & $1886-1890$ \\
\hline Smallmans & Bootmaker & $1896-1965$ (1980) \\
\hline E M G Croxton & Restaurant & $1896-1901$ \\
\hline H G Stephenson ${ }^{\neq}$ & Florist & $1896-1901$ \\
\hline J Critchley & Earthenware dealer & 1905 \\
\hline Barton Arcade Café & Fancy repository & 1905 \\
\hline Samuel Porter \& Co & Restaurant & $1911-1924$ \\
\hline Squirrel Café & Waterproofers & $1915-1939$ \\
\hline Francois \& Co & Restaurant & $1933-1954$ \\
\hline Ellwood Silks (later Ellwoods) & Costumiers & \\
\hline Vent Axia & Silk merchant (later Drapery) & $1939-1965$ (1975) \\
\hline Fleming, Reid \& Co & Ventilating fan makers & $1954-1957$ \\
\hline Frank Wine \& Sons & Scotch wool hosiery stores & $1954-1965$ (1969) \\
\hline $\begin{array}{l}\text { Coal Utilisation Council (later } \\
\text { Solid Fuels Advisory Service) }\end{array}$ & Silversmiths & $1957-1965$ \\
\hline Lawleys Ltd & Information centre & $1957-1965(1975)$ \\
\hline & China \& glass & \\
\hline & & $1965-(1973)$ \\
\hline
\end{tabular}

Notes:

* Ordered chronologically by appearance in retail directories

\# Indicates the first and last year the retailer appeared in the retail directories under study, between 1876-

1965. Date in brackets indicate the final appearance of the retailer in subsequent Goad plans

* This is an additional unit to the ones occupied by H G Stephenson (China \& glass dealer) and only appears in the 1905 directory 
Table 2: Unit Occupancy 1967-2018 from Goad Plans

\begin{tabular}{|c|c|c|c|c|c|c|c|}
\hline & 1967 & 1969 & 1971 & 1973 & 1975 & 1977 & 1980 \\
\hline $1 ¥$ & \multirow[t]{5}{*}{$\begin{array}{l}\text { Ellwoods } \\
\text { Drapery }\end{array}$} & \multirow[t]{5}{*}{$\begin{array}{l}\text { Ellwoods } \\
\text { Drapery }\end{array}$} & \multirow[t]{5}{*}{$\begin{array}{l}\text { Ellwoods } \\
\text { Drapery }\end{array}$} & \multirow[t]{5}{*}{$\begin{array}{l}\text { Ellwoods } \\
\text { Drapery }\end{array}$} & \multirow{5}{*}{$\begin{array}{l}\text { Ellwoods } \\
\text { Drapery } \\
\text { (To be } \\
\text { Vacant) }\end{array}$} & \multirow{5}{*}{$\begin{array}{l}\text { Astonishing } \\
\text { Shoes } \\
\text { Footwear } \\
\text { (To be } \\
\text { Vacated) }\end{array}$} & \multirow[t]{5}{*}{ VACANT } \\
\hline $2 ¥$ & & & & & & & \\
\hline $8 ¥$ & & & & & & & \\
\hline $9 ¥$ & & & & & & & \\
\hline $10 ¥$ & & & & & & & \\
\hline 3 & $\begin{array}{l}\text { Manfield } \\
\text { Footwear }\end{array}$ & $\begin{array}{l}\text { Manfield } \\
\text { Footwear }\end{array}$ & $\begin{array}{l}\text { Manfield } \\
\text { Footwear }\end{array}$ & $\begin{array}{l}\text { Manfield } \\
\text { Footwear }\end{array}$ & $\begin{array}{l}\text { Manfield } \\
\text { Footwear }\end{array}$ & $\begin{array}{l}\text { Manfield } \\
\text { Footwear }\end{array}$ & $\begin{array}{l}\text { Manfield } \\
\text { Footwear }\end{array}$ \\
\hline 4 & $\begin{array}{l}\text { Fleming, Reid } \\
\text { \& Co \# } \\
\text { Wool \& } \\
\text { Hosiery }\end{array}$ & $\begin{array}{l}\text { Fleming, Reid } \\
\text { \& Co \# } \\
\text { Wool \& } \\
\text { Hosiery }\end{array}$ & $\begin{array}{l}\text { Bellmans } \\
\text { Ladieswear \& } \\
\text { Knitwear }\end{array}$ & $\begin{array}{l}\text { Bellmans } \\
\text { Ladieswear \& } \\
\text { Knitwear }\end{array}$ & VACANT & $\begin{array}{l}\text { Stephens } \\
\text { Gifts }\end{array}$ & $\begin{array}{l}\text { Stephens } \\
\text { Gifts }\end{array}$ \\
\hline 5 & $\begin{array}{l}\text { Carley's } \\
\text { Ladieswear }\end{array}$ & $\begin{array}{l}\text { Alfred Marks } \\
\text { Employment } \\
\text { Bureau }\end{array}$ & $\begin{array}{l}\text { Alfred Marks } \\
\text { Employment } \\
\text { Bureau }\end{array}$ & $\begin{array}{l}\text { Alfred Marks } \\
\text { Employment } \\
\text { Bureau }\end{array}$ & $\begin{array}{l}\text { Alfred Marks } \\
\text { Employment } \\
\text { Bureau }\end{array}$ & $\begin{array}{l}\text { Alfred Marks } \\
\text { Employment } \\
\text { Bureau }\end{array}$ & VACANT \\
\hline 6 & $\begin{array}{l}\text { J Edwards } \\
\text { Footwear }\end{array}$ & $\begin{array}{l}\text { J Edwards } \\
\text { Footwear }\end{array}$ & $\begin{array}{l}\text { J Edwards } \\
\text { Footwear }\end{array}$ & $\begin{array}{l}\text { J Edwards } \\
\text { Footwear }\end{array}$ & $\begin{array}{l}\text { J Edwards } \\
\text { Footwear }\end{array}$ & $\begin{array}{l}\text { J Edwards } \\
\text { Footwear }\end{array}$ & $\begin{array}{l}\text { J Edwards } \\
\text { Footwear }\end{array}$ \\
\hline 7 & $\begin{array}{l}\text { Stuarts } \\
\text { Ladieswear }\end{array}$ & $\begin{array}{l}\text { Stuarts } \\
\text { Ladieswear }\end{array}$ & $\begin{array}{l}\text { Stuarts } \\
\text { Ladieswear }\end{array}$ & $\begin{array}{l}\text { Stuarts } \\
\text { Ladieswear }\end{array}$ & $\begin{array}{l}\text { Stuarts } \\
\text { Ladieswear }\end{array}$ & $\begin{array}{l}\text { Stuarts } \\
\text { Ladieswear }\end{array}$ & $\begin{array}{l}\text { Stuarts } \\
\text { Ladieswear }\end{array}$ \\
\hline $11 ¥$ & \multirow{2}{*}{$\begin{array}{l}\text { Lawleys } \\
\text { Glass/China }\end{array}$} & \multirow{2}{*}{$\begin{array}{l}\text { Lawleys } \\
\text { Glass/China }\end{array}$} & \multirow{2}{*}{$\begin{array}{l}\text { Lawleys } \\
\text { Glass/China }\end{array}$} & \multirow{2}{*}{$\begin{array}{l}\text { Lawleys } \\
\text { Glass/China }\end{array}$} & \multirow{2}{*}{$\begin{array}{l}\text { Italia Import } \\
\text { \& Export Co } \\
\text { Furniture }\end{array}$} & \multirow[t]{2}{*}{ VACANT } & \multirow[t]{2}{*}{ VACANT } \\
\hline $12 ¥$ & & & & & & & \\
\hline 13 & $\begin{array}{l}\text { Coal } \\
\text { Utilisation } \\
\text { Council } \\
\text { Commercial }\end{array}$ & $\begin{array}{l}\text { Coal } \\
\text { Utilisation } \\
\text { Council } \\
\text { Commercial }\end{array}$ & $\begin{array}{l}\text { Coal } \\
\text { Utilisation } \\
\text { Council } \\
\text { Commercial }\end{array}$ & $\begin{array}{l}\text { Coal } \\
\text { Utilisation } \\
\text { Council } \\
\text { Commercial }\end{array}$ & $\begin{array}{l}\text { Solid Fuel } \\
\text { Advisory } \\
\text { Service } \\
\text { Commercial }\end{array}$ & VACANT & VACANT \\
\hline
\end{tabular}




\begin{tabular}{|c|c|c|c|c|c|c|c|}
\hline SHOP & 1983 & 1986 & 1988 & 1990 & 1993 & 1996 & 1998 \\
\hline 1 & $\begin{array}{l}\text { Mazels } \\
\text { Video City } \\
\text { Video Shop } \\
\end{array}$ & $\begin{array}{l}\text { Fast Frame } \\
\text { Picture } \\
\text { Framing } \\
\end{array}$ & $\begin{array}{l}\text { Fast Frame } \\
\text { Picture } \\
\text { Framing } \\
\end{array}$ & $\begin{array}{l}\text { Fast Frame } \\
\text { Picture } \\
\text { Framing } \\
\end{array}$ & $\begin{array}{l}\text { Fast Frame } \\
\text { Picture } \\
\text { Framing } \\
\end{array}$ & $\begin{array}{l}\text { Fast Frame } \\
\text { Picture } \\
\text { Framing } \\
\end{array}$ & $\begin{array}{l}\text { Fast Frame } \\
\text { Picture } \\
\text { Framing } \\
\end{array}$ \\
\hline 2 & $\begin{array}{l}\text { Wardrobe } \\
\text { Menswear }\end{array}$ & $\begin{array}{l}\text { Wardrobe } \\
\text { Menswear }\end{array}$ & $\begin{array}{l}\text { Wardrobe } \\
\text { Menswear }\end{array}$ & $\begin{array}{l}\text { Wardrobe } \\
\text { Menswear }\end{array}$ & $\begin{array}{l}\text { Wardrobe } \\
\text { Menswear }\end{array}$ & $\begin{array}{l}\text { Wardrobe } \\
\text { Menswear }\end{array}$ & VACANT \\
\hline 8 & VACANT & $\begin{array}{l}\text { Lisa Stirling } \\
\text { Ladieswear }\end{array}$ & $\begin{array}{l}\text { Lisa Stirling } \\
\text { Ladieswear }\end{array}$ & $\begin{array}{l}\text { Sportsfeet } \\
\text { Footwear }\end{array}$ & $\begin{array}{l}\text { Austravel } \\
\text { Travel Agent }\end{array}$ & $\begin{array}{l}\text { Austravel } \\
\text { Travel Agent }\end{array}$ & $\begin{array}{l}\text { Austravel } \\
\text { Travel Agent }\end{array}$ \\
\hline $9 ¥$ & VACANT & \multirow{2}{*}{$\begin{array}{l}\text { Osborne \& } \\
\text { Little } \\
\text { Soft } \\
\text { Furnishings } \\
\end{array}$} & \multirow{2}{*}{$\begin{array}{l}\text { Osborne \& } \\
\text { Little } \\
\text { Soft } \\
\text { Furnishings }\end{array}$} & \multirow[t]{2}{*}{ VACANT } & \multirow{2}{*}{$\begin{array}{l}\text { Richard } \\
\text { Crème } \\
\text { Ladieswear }\end{array}$} & $\begin{array}{l}\text { Jill Black } \\
\text { Ladieswear }\end{array}$ & $\begin{array}{l}\text { Jill Black } \\
\text { Ladieswear }\end{array}$ \\
\hline $10 ¥$ & VACANT & & & & & VACANT & $\begin{array}{l}\text { William Hunt } \\
\text { Menswear }\end{array}$ \\
\hline 3 & VACANT & $\begin{array}{l}\text { City Lights } \\
\text { Lighting }\end{array}$ & $\begin{array}{l}\text { City Lights } \\
\text { Lighting }\end{array}$ & $\begin{array}{l}\text { City Lights } \\
\text { Lighting }\end{array}$ & $\begin{array}{l}\text { City Lights } \\
\text { Lighting }\end{array}$ & $\begin{array}{l}\text { City Lights } \\
\text { Lighting }\end{array}$ & $\begin{array}{l}\text { House of } \\
\text { Lamps } \\
\text { Lighting }\end{array}$ \\
\hline 4 & $\begin{array}{l}\text { Sunbright } \\
\text { Travel } \\
\text { Agent }\end{array}$ & $\begin{array}{l}\text { Sunbright } \\
\text { Travel Agent }\end{array}$ & $\begin{array}{l}\text { Sunbright } \\
\text { Travel Agent }\end{array}$ & $\begin{array}{l}\text { J S Peters } \\
\text { Menswear }\end{array}$ & $\begin{array}{l}\text { Elysee } \\
\text { Ladieswear }\end{array}$ & $\begin{array}{l}\text { Elysee } \\
\text { Ladieswear }\end{array}$ & $\begin{array}{l}\text { Howard \& } \\
\text { Drews } \\
\text { Jewellery }\end{array}$ \\
\hline 5 & VACANT & $\begin{array}{l}\text { Oddbins } \\
\text { Off- Licence }\end{array}$ & $\begin{array}{l}\text { Oddbins } \\
\text { Off-Licence }\end{array}$ & $\begin{array}{l}\text { Oddbins } \\
\text { Off-Licence }\end{array}$ & $\begin{array}{l}\text { Oddbins } \\
\text { Off-Licence }\end{array}$ & $\begin{array}{l}\text { Oddbins } \\
\text { Off-Licence }\end{array}$ & $\begin{array}{l}\text { Oddbins } \\
\text { Off-Licence }\end{array}$ \\
\hline 6 & $\begin{array}{l}\text { J Edwards } \S \\
\text { Footwear }\end{array}$ & $\begin{array}{l}\text { J Edwards } \\
\text { Footwear }\end{array}$ & $\begin{array}{l}\text { J Edwards } \\
\text { Footwear }\end{array}$ & $\begin{array}{l}\text { J Edwards } \\
\text { Footwear }\end{array}$ & $\begin{array}{l}\text { J Edwards } \\
\text { Footwear }\end{array}$ & $\begin{array}{l}\text { J Edwards } \\
\text { Footwear }\end{array}$ & $\begin{array}{l}\text { J Edwards } \\
\text { Footwear }\end{array}$ \\
\hline 7 & $\begin{array}{l}\text { Stuarts } \\
\text { Ladieswear }\end{array}$ & $\begin{array}{l}\text { Dickens } \\
\text { Menswear }\end{array}$ & $\begin{array}{l}\text { Dickens } \\
\text { Menswear }\end{array}$ & $\begin{array}{l}\text { Dickens } \\
\text { Menswear }\end{array}$ & $\begin{array}{l}\text { Dickens } \\
\text { Menswear }\end{array}$ & $\begin{array}{l}\text { Dickens } \\
\text { Menswear }\end{array}$ & $\begin{array}{l}\text { Dickens } \\
\text { Menswear }\end{array}$ \\
\hline $11 ¥$ & VACANT & $\begin{array}{l}\text { Ganders } \\
\text { Wine Bar }\end{array}$ & $\begin{array}{l}\text { Ganders } \\
\text { Wine Bar }\end{array}$ & $\begin{array}{l}\text { Oilily } \\
\text { Ladies \& } \\
\text { Childswear } \\
\end{array}$ & $\begin{array}{l}\text { Oilily } \\
\text { Ladies \& } \\
\text { Childswear } \\
\end{array}$ & $\begin{array}{l}\text { Oilily } \\
\text { Ladies \& } \\
\text { Childswear } \\
\end{array}$ & $\begin{array}{l}\text { Oilily } \\
\text { Childswear }\end{array}$ \\
\hline $12 ¥$ & & & & $\begin{array}{l}\text { Scallywags } \\
\text { Childswear }\end{array}$ & $\begin{array}{l}\text { Scallywags } \\
\text { Childswear }\end{array}$ & $\begin{array}{l}\text { Scallywags } \\
\text { Childswear }\end{array}$ & $\begin{array}{l}\text { Scallywags } \\
\text { Childswear }\end{array}$ \\
\hline $12 a \neq$ & & & & VACANT & $\begin{array}{l}\text { Design a } \\
\text { Sandwich } \\
\text { Food } \\
\end{array}$ & $\begin{array}{l}\text { Design a } \\
\text { Sandwich } \\
\text { Food } \\
\end{array}$ & $\begin{array}{l}\text { Design a } \\
\text { Sandwich } \\
\text { Food } \\
\end{array}$ \\
\hline $12 b \neq$ & & $\begin{array}{l}\text { Handbag } \\
\text { Shop } \\
\text { Accessories }\end{array}$ & $\begin{array}{l}\text { Handbag } \\
\text { Shop } \\
\text { Accessories }\end{array}$ & $\begin{array}{l}\text { Wearout } \\
\text { Ladieswear }\end{array}$ & VACANT & $\begin{array}{l}\text { Geese } \pm \\
\text { Ladieswear }\end{array}$ & VACANT \\
\hline 13 & VACANT & VACANT & $\begin{array}{l}\text { Ersan } \\
\#\end{array}$ & $\begin{array}{l}\text { Ersan } \\
\#\end{array}$ & $\begin{array}{l}\text { Jade } \\
\# \\
\end{array}$ & $\begin{array}{l}\text { Geese } \pm \\
\text { Ladieswear }\end{array}$ & VACANT \\
\hline
\end{tabular}




\begin{tabular}{|c|c|c|c|c|c|c|c|c|}
\hline SHOP & 2000 & 2003 & 2006 & 2008 & 2010 & 2013 & 2015 & 2018 \\
\hline 1 & VACANT & $\begin{array}{l}\text { Intro } \\
\text { Menswear }\end{array}$ & $\begin{array}{l}\text { Intro } \\
\text { Menswear }\end{array}$ & $\begin{array}{l}\text { Intro } \\
\text { Menswear }\end{array}$ & $\begin{array}{l}\text { Intro } \\
\text { Menswear }\end{array}$ & $\begin{array}{l}\text { Intro } \\
\text { Menswear }\end{array}$ & $\begin{array}{l}\text { Intro } \\
\text { Menswear }\end{array}$ & $\begin{array}{l}\text { Intro } \\
\text { Menswear }\end{array}$ \\
\hline 2 & $\begin{array}{l}\text { Haircuttery } \\
\text { Hairdressing }\end{array}$ & $\begin{array}{l}\text { Haircuttery } \\
\text { Hairdressing }\end{array}$ & $\begin{array}{l}\text { HCUK } \\
\text { Hairdressing }\end{array}$ & $\begin{array}{l}\text { HCUK } \\
\text { Hairdressing }\end{array}$ & $\begin{array}{l}\text { Hair } 1 \text { UK } \\
\text { Hairdressing }\end{array}$ & $\begin{array}{l}\text { Too Funky } \\
\text { Hair } \\
\text { Hairdressing }\end{array}$ & $\begin{array}{l}\text { Too Funky } \\
\text { Hair } \\
\text { Hairdressing }\end{array}$ & VACANT \\
\hline 8 & $\begin{array}{l}\text { Austravel } \\
\text { Travel Agent }\end{array}$ & $\begin{array}{l}\text { Austravel } \\
\text { Travel Agent }\end{array}$ & $\begin{array}{l}\text { Austravel } \\
\text { Travel Agent }\end{array}$ & $\begin{array}{l}\text { Austravel } \\
\text { Travel Agent }\end{array}$ & $\begin{array}{l}\text { Austravel } \\
\text { Travel Agent }\end{array}$ & VACANT & $\begin{array}{l}\text { Clean Cuts } \\
\text { Hairdressing }\end{array}$ & $\begin{array}{l}\text { Barber } \\
\text { Barber } \\
\text { Hairdressing }\end{array}$ \\
\hline 9 & $\begin{array}{l}\text { Jill Black } \\
\text { Ladieswear }\end{array}$ & $\begin{array}{l}\text { Jill Black } \\
\text { Ladieswear }\end{array}$ & $\begin{array}{l}\text { Jill Black } \\
\text { Ladieswear }\end{array}$ & $\begin{array}{l}\text { Jill Black } \\
\text { Ladieswear }\end{array}$ & $\begin{array}{l}\text { Jill Black } \\
\text { Ladieswear }\end{array}$ & $\begin{array}{l}\text { Jill Black } \\
\text { Ladieswear }\end{array}$ & $\begin{array}{l}\text { Jill Black } \\
\text { Ladieswear }\end{array}$ & VACANT \\
\hline 10 & $\begin{array}{l}\text { Scallywags } \\
\text { Childswear }\end{array}$ & $\begin{array}{l}\text { Scallywags } \\
\text { Childswear }\end{array}$ & $\begin{array}{l}\text { Oilily } \\
\text { Ladieswear }\end{array}$ & $\begin{array}{l}\text { Jeffery West } \\
\text { Footwear }\end{array}$ & $\begin{array}{l}\text { Jeffery West } \\
\text { Footwear }\end{array}$ & $\begin{array}{l}\text { Jeffery West } \\
\text { Footwear }\end{array}$ & $\begin{array}{l}\text { Jeffery West } \\
\text { Footwear }\end{array}$ & $\begin{array}{l}\text { Jeffery West } \\
\text { Footwear }\end{array}$ \\
\hline 3 & $\begin{array}{l}\text { House of } \\
\text { Lamps } \\
\text { Lighting }\end{array}$ & $\begin{array}{l}\text { House of } \\
\text { Lamps } \\
\text { Lighting }\end{array}$ & $\begin{array}{l}\text { Olivee } \\
\text { Café \& Deli }\end{array}$ & VACANT & VACANT & $\begin{array}{l}\text { STA Travel } \\
\text { Travel Agent }\end{array}$ & $\begin{array}{l}\text { STA Travel } \\
\text { Travel Agent }\end{array}$ & $\begin{array}{l}\text { STA Travel } \\
\text { Travel Agent }\end{array}$ \\
\hline 4 & VACANT & $\begin{array}{l}\text { Futon } \\
\text { Company } \\
\text { Furniture }\end{array}$ & $\begin{array}{l}\text { Futon } \\
\text { Company } \\
\text { Furniture }\end{array}$ & $\begin{array}{l}\text { General } \\
\text { Store } \\
\text { Menswear }\end{array}$ & $\begin{array}{l}\text { General } \\
\text { Store } \\
\text { Menswear }\end{array}$ & $\begin{array}{l}\text { Each to Their } \\
\text { Own } \\
\text { Ladies \& } \\
\text { Menswear }\end{array}$ & VACANT & \multirow[t]{2}{*}{$\begin{array}{l}\text { Lunya } \\
\text { Restaurant \& } \\
\text { Deli }\end{array}$} \\
\hline 5 & $\begin{array}{l}\text { Oddbins } \\
\text { Off-Licence }\end{array}$ & $\begin{array}{l}\text { Oddbins } \\
\text { Off-Licence }\end{array}$ & $\begin{array}{l}\text { Oddbins } \\
\text { Off-Licence }\end{array}$ & $\begin{array}{l}\text { Nicholas } \\
\text { Off-Licence }\end{array}$ & $\begin{array}{l}\text { Nicholas } \\
\text { Off-Licence }\end{array}$ & $\begin{array}{l}\text { Spirited } \\
\text { Wines } \\
\text { Off-Licence } \\
\end{array}$ & VACANT & \\
\hline 6 & $\begin{array}{l}\text { J Edwards } \\
\text { Footwear }\end{array}$ & $\begin{array}{l}\text { J Edwards } \\
\text { Footwear }\end{array}$ & $\begin{array}{l}\text { J Edwards } \\
\text { Footwear }\end{array}$ & $\begin{array}{l}\text { J Edwards } \\
\text { Footwear }\end{array}$ & $\begin{array}{l}\text { J Edwards } \\
\text { Footwear }\end{array}$ & $\begin{array}{l}\text { J Edwards } \\
\text { Footwear }\end{array}$ & $\begin{array}{l}\text { J Edwards } \\
\text { Footwear }\end{array}$ & VACANT \\
\hline 7 & $\begin{array}{l}\text { Dickens } \\
\text { Menswear }\end{array}$ & VACANT & $\begin{array}{l}\text { Suburb } \\
\text { Café }\end{array}$ & $\begin{array}{l}\text { Oilily } \\
\text { Ladies \& } \\
\text { Childswear }\end{array}$ & $\begin{array}{l}\text { Ed Hardy } \\
\text { Menswear }\end{array}$ & VACANT & $\begin{array}{l}\text { Spirited } \\
\text { Wines } \\
\text { Off-Licence }\end{array}$ & $\begin{array}{l}\text { Sync } \\
\text { Electrical } \\
\text { Goods }\end{array}$ \\
\hline $11 ¥$ & $\begin{array}{l}\text { Oilily } \\
\text { Childswear }\end{array}$ & $\begin{array}{l}\text { Oilily } \\
\text { Childswear }\end{array}$ & $\begin{array}{l}\text { Oilily } \\
\text { Childswear }\end{array}$ & VACANT & \multirow[t]{2}{*}{$\begin{array}{l}\text { Kitchen } \\
\text { Cafe }\end{array}$} & VACANT & \multirow[t]{2}{*}{$\begin{array}{l}\text { PotKettle } \\
\text { Black } \\
\text { Café }\end{array}$} & \multirow[t]{4}{*}{$\begin{array}{l}\text { PotKettle } \\
\text { Black } \\
\text { Café }\end{array}$} \\
\hline $12 ¥$ & VACANT & VACANT & $\begin{array}{l}\text { Phil Black } \\
\text { Menswear }\end{array}$ & VACANT & & VACANT & & \\
\hline $12 a \neq$ & $\begin{array}{l}\text { Design a } \\
\text { Sandwich } \\
\text { Food }\end{array}$ & $\begin{array}{l}\text { Design a } \\
\text { Sandwich } \\
\text { Food }\end{array}$ & $\begin{array}{l}\text { Design a } \\
\text { Sandwich } \\
\text { Food }\end{array}$ & $\begin{array}{l}\text { Design a } \\
\text { Sandwich } \\
\text { Food }\end{array}$ & $\begin{array}{l}\text { Design a } \\
\text { Sandwich } \\
\text { Food }\end{array}$ & $\begin{array}{l}\text { Design a } \\
\text { Sandwich } \\
\text { Food }\end{array}$ & $\begin{array}{l}\text { Design a } \\
\text { Sandwich } \\
\text { Food }\end{array}$ & \\
\hline $12 b ¥$ & VACANT & VACANT & $\begin{array}{l}\text { Co-Cu } \pm \\
\text { Ladieswear }\end{array}$ & $\begin{array}{l}\text { Co-Cu } \pm \\
\text { Ladieswear }\end{array}$ & $\begin{array}{l}\text { Co-Cu } \pm \\
\text { Ladieswear }\end{array}$ & $\begin{array}{l}\text { Electronic } \\
\text { Cigarette } \\
\text { Shop } \\
\text { Business } \\
\text { Equipment }\end{array}$ & VACANT & \\
\hline 13 & VACANT & $\begin{array}{l}\text { Zhade Shoes } \\
\text { Footwear }\end{array}$ & $\begin{array}{l}\text { Co-Cu } \pm \\
\text { Bridalwear }\end{array}$ & $\begin{array}{l}\text { Co-Cu } \pm \\
\text { Bridalwear }\end{array}$ & $\begin{array}{l}\text { Co-Cu } \pm \\
\text { Bridalwear }\end{array}$ & VACANT & VACANT & $\begin{array}{l}\text { Rstore } \\
\text { Menswear \& } \\
\text { Footwear }\end{array}$ \\
\hline
\end{tabular}

Notes:

\# Illegible information on occupant and/or product category on handwritten Goad plans. Retailer identified from relevant Kelly's Directories.

¥ Some units in the original plan were subsequently amalgamated or split over the years. This is particularly the case with the original Unit 12, subdivided into three separate units from the mid-1980s onwards. This subdivision is notated by using Units $12,12 \mathrm{a}$ and $12 \mathrm{~b}$.

$\S$ In the 1983 Goad plan, the J Edwards store (Unit 5) had been extended to incorporate part of Unit 13, thereby increasing its spatial footprint, and correspondingly reducing that of Unit 13.

\pm On some plans, Unit $12 \mathrm{~b}$ and Unit 13, which are either side of a pedestrian way to an entrance/exit at the back of Barton Arcade, despite being physically separate units were occupied by a single company. 


\section{Notes}

\footnotetext{
${ }^{1}$ Ronald Savitt, 'Historical research in marketing', Journal of Marketing, 44 Fall (1980): 52-58. Page 52.

${ }^{2}$ Stanley Hollander, 'A rearview mirror might help us drive forward: a call for more historical studies in retailing', Journal of Retailing, 62, no. 1 (1986): 7-10. Page 7.

${ }^{3}$ Nicholas Alexander, 'Retail history in the management context: prototype, prologue or prequel?', Journal of Historical Research in Marketing, 2 no. 3 (2010): 350-355. Page 350

${ }^{4}$ Nicholas Alexander, 'Objects in the rearview mirror may appear closer than they are', International Journal of Retail, Distribution and Consumer Research, 7 no. 4 (1997): 383-403. Page 384.

${ }^{5}$ See Alexander, 'Retail history in the management context: prototype, prologue or prequel?'; and Andrew Alexander, 'Past, present and future directions in the study of the history of retailing', Journal of Historical Research in Marketing, 2 no. 3 (2010): 356-362.

${ }^{6}$ Alexander, 'Objects in the rearview mirror may appear closer than they are'.

7 Johann Friedrich Geist, Arcades: The History of a Building Type (Cambridge MA \& London: The MIT Press). Page 4.

${ }^{8}$ For discussions of the historical development of arcades see: Geist, Arcades The History of a Building Type;
} also Vicki Howard and Jon Stobart, 'Arcades, shopping centres and shopping malls' in J. Stobart and V. Howard (eds.) The Routledge Companion to the History of Retailing, (London: Routledge, 2018) pp. 195-213; and Peter Coleman, Shopping Environments: Evolution, Planning and Design (Oxford and Burlington MA: Architectural Press, 2006).

${ }^{9}$ Margaret MacKeith, Shopping Arcades A Gazetteer of Extant British Arcades 1817-1939 (London \& New York: Mansell Publishing Limited, 1985)

${ }^{10}$ Howard and Stobart, 'Arcades, shopping centres and shopping malls'

${ }^{11}$ MacKeith, Shopping Arcades A Gazetteer of Extant British Arcades 1817-1939, 2.

12 Howard and Stobart, 'Arcades, shopping centres and shopping malls', 197.

${ }^{13}$ See Geist, Arcades The History of a Building Type; Howard and Stobart, 'Arcades, shopping centres and shopping malls'; and MacKeith, Shopping Arcades A Gazetteer of Extant British Arcades 1817-1939 for more detail.

${ }^{14}$ Howard and Stobart, 'Arcades, shopping centres and shopping', 198.

${ }^{15}$ MacKeith, Shopping Arcades A Gazetteer of Extant British Arcades 1817-1939, 21.

${ }^{16}$ Kathryn Morrison, English Shops and Shopping: An Architectural History, 107.

${ }^{17}$ Geist, Arcades The History of a Building Type, 82.

18 Morrison, English Shops and Shopping: An Architectural History (New Haven \& London: Yale University Press/English Heritage, 2003). Page 107.

19 MacKeith, The History and Conservation of Shopping Arcades, 21.

${ }^{20}$ For more extensive discussion see Geoffrey Crossick and Serge Jaumain, 'The world of the department store: distribution, culture and social change' In G. Crossick and S. Jaumain (eds.) Cathedrals of Consumption: The European Department Store, 1850-1939 (Aldershot: Gower, 1999), 1-45; and Bill Lancaster, The Department Store: A Social History (London and New York: Leicester University Press, 1995).

${ }^{21}$ Howard and Stobart, 'Arcades, shopping centres and shopping', 199.

${ }^{22}$ Geist, Arcades The History of a Building Type, 121-569.

${ }^{23}$ MacKeith, Shopping Arcades A Gazetteer of Extant British Arcades 1817-1939, 3-139.

${ }^{24}$ Bie Plevoets and Koenraad Van Cleempoel, 'Assessing authenticity of nineteenth century shopping passages', Journal of Cultural Heritage Management and Sustainable Development, 1 no. 2 (2011): 135-156.

${ }^{25}$ Plevoets and Van Cleepoel, 'Assessing authenticity of nineteenth century shopping passages', 138-140.

${ }^{26}$ See Morrison, English Shops and Shopping: An Architectural History, specifically relating to Burlington Arcade, 99-101.

${ }^{27}$ For more extensive discussion, see Claire Walsh, 'Social meaning and social space in the shopping galleries of early modern London' In J. Benson and L. Ugolini (eds.), A Nation of Shopkeepers: Five Centuries of British Retailing (London \& New York: I. B. Taurus, 2003), 52-79.

${ }^{28}$ Plevoets and Van Cleepoel, 'Assessing authenticity of nineteenth century shopping passages', 139-40

${ }^{29}$ Ibid., 140-141

${ }^{30}$ See Howard and Stobart, 'Arcades, shopping centres and shopping', 198-199; Morrison, English Shops and Shopping: An Architectural History, 101-105.

${ }^{31}$ MacKeith, Shopping Arcades A Gazetteer of Extant British Arcades 1817-1939, 153-158. 
32 Kevin Grady, 'Commercial marketing and retailing amenities, 1700-1914', in D. Fraser (ed) A History of Modern Leeds (Manchester: Manchester University Press) pp. 177-199. Page 195.

33 Ibid., 195

${ }^{34}$ For a full description of all five Manchester arcades, see Geist, Arcades The History of a Building Type, 350363.

35 Ibid., 351

${ }^{36}$ Historic England, Bartons Building including Barton Arcade. Available at https://historicengland.org.uk/listing/the-list/list-entry/1200850 [Accessed 8 October 2018].

${ }^{37}$ Halle Bertramsen, Rethinking the Victorian Department Store: Manchester's Two Emporia: Kendal Milne and Lewis's 1836-1890 (Unpublished PhD Thesis, University of Lancaster, 2002).

${ }^{38}$ Bertramsen, Rethinking the Victorian Department Store: Manchester's Two Emporia: Kendal Milne and Lewis's 1836-1890, and also Halle Bertramsen, 'Remoulding commercial space: municipal improvements and the department store in late-Victorian Manchester', in J. Benson and L. Ugolini (eds.) A Nation of Shopkeepers: Five Centuries of British Retailing (London \& New York: I B Tauris) pp. 206-225.

${ }^{39}$ Bertramsen, Rethinking the Victorian Department Store: Manchester's Two Emporia: Kendal Milne and Lewis's 1836-1890, 135.

${ }^{40}$ Bertramsen, Rethinking the Victorian Department Store: Manchester's Two Emporia: Kendal Milne and Lewis's 1836-1890, 89-91.

${ }^{41}$ Bertramsen, Rethinking the Victorian Department Store: Manchester's Two Emporia: Kendal Milne and Lewis's 1836-1890, 119.

${ }^{42}$ Clare Hartwell, Matthew Hyde and Nikolaus Pevsner, The Buildings of England - Lancashire: Manchester and the South East. (New Haven \& London: Yale University Press). Page 346.

${ }^{43}$ Geist, Arcades The History of a Building Type, 351.

${ }^{44}$ See Geist, Arcades The History of a Building Type, 351-356; and MacKeith, Shopping Arcades A Gazetteer of Extant British Arcades 1817-1939, page 98 for detailed descriptions of the architectural characteristics of Barton Arcade.

${ }^{45}$ Gareth Shaw, G. and Allison Tipper, British Directories: A Bibliography and Guide to Directories Published in England and Wales (1850-1950) and Scotland (1773-1950), (London and New York: Leicester University Press, 1989).

${ }^{46}$ Gwyn Rowley and Peter McL. Shepherd, 'A source of elementary spatial data for town centre research in Britain', Area, 8 no. 3 (1976): 201-208. Page 207.

${ }^{47}$ See https://buildingourpast.com/2016/09/04/manfield-sons-shoes-of-bespoke-character/ for more detail on this company.

48 MacKeith, Shopping Arcades A Gazetteer of Extant British Arcades 1817-1939, 98.

49 MacKeith, Shopping Arcades A Gazetteer of Extant British Arcades 1817-1939, 98.

${ }^{50}$ MacKeith, The History and Conservation of Shopping Arcades, 134.

${ }^{51}$ MacKeith, The History and Conservation of Shopping Arcades, 135.

52 Bertramsen, Rethinking the Victorian Department Store: Manchester's Two Emporia: Kendal Milne and Lewis's 1836-1890, 119.

53 Walsh, 'Social meaning and social space in the shopping galleries of early modern London', 62-67.

${ }^{54}$ Howard and Stobart, 'Arcades, shopping centres and shopping', 197-198.

${ }^{55}$ Emily Heward, 'Manchester's Barton Arcade to open a $£ 200$ a year rooftop bar and basement members lounge', Manchester Evening News, 27 February 2018. Available at

https://www.manchestereveningnews.co.uk/whats-on/whats-on-news/manchesters-barton-arcade-openrooftop-14339460 [Accessed 31 August 2018].

${ }^{56}$ For more detail, see Bie Plevoets and Koenraad Van Cleepoel, 'Creating sustainable retail interiors through the reuse of historic buildings', Interiors, 3 no. 3 (2012), 271-292; and Bie Plevoets and Koenraad Van Cleepoel, 'Aemulatio and the interior approach of adaptive reuse', Interiors, 5 no. 1 (2014), 71-88.

57 Stephen Brown, Retail Location: A Micro-Scale Perspective (Aldershot: Avebury, 1992), xiii.

${ }^{58}$ Stephen Brown, 'Micro-scale retail location: Cinderella or ugly sister?', International Journal of Retail and Distribution Management, 21 no 7 (1993), 10-19. Page 18.

${ }^{59}$ See Giovanni Levi, 'On microhistory', in P. Burke (ed.) New Perspectives on Historical Writing. (Cambridge: Polity Press, 1991): 93-113; and also Carlo Ginzberg, 'Microhistory: two or three things that I know about it', Critical Inquiry, 20 Autumn (1993): 10-35.

60 Levi, 'On microhistory', 98.

${ }^{61}$ See Levi, 'On microhistory'; and Sigurdur G Magnússon, 'The singularization of history: Social history and microhistory within the postmodern state of knowledge'. Journal of Social History, 36 no. 3 (2003), 701-735. 
${ }^{62}$ Ginzberg, 'Microhistory: two or three things that I know about it', 32-34.

${ }^{63}$ Levi, 'On microhistory', 106.

${ }^{64}$ Ibid., 97. 